\title{
Improving Student Learning Outcomes through School Culture, Work Motivation and Teacher Performance
}

\section{Onisimus Amtu}

Asst. Prof., (Lector) at Christian Religion Education Departement, Institut Agama Kristen Negeri Ambon, Maluku, Indonesia, amtuonisimus@gmail.com

\section{Korlina Makulua}

Asst. Prof., (Lector) at Early Childhood Education Departement, Institut Agama Kristen Negeri Ambon, Maluku, Indonesia, kakomakulua@gmail.com

\section{Jacoba Matital}

Asst. Prof., (Lector) at Early Childhood Education Departement, Institut Agama Kristen Negeri Ambon, Maluku, Indonesia, rafaraina24@gmail.com

\section{Claudia Monique Pattiruhu}

Asst. Prof., (Lector) at Early Childhood Education Departement, Institut Agama Kristen Negeri Ambon, Maluku, Indonesia,nona_clamopat@yahoo.com

This study aims to investigate the direct and indirect effects of school culture and work motivation on student learning outcomes through teacher performance. This study was designed according to quantitative methods and used a questionnaire as a data collection instrument and purposive sampling technique to determine a sample of 213 Christian religious education teachers as participants in Teacher Professional Education (TPE) from 26 provinces in Indonesia. This study presents a path analysis diagram model to analyze the value of the influence of exogenous variables on endogenous variables through intervening variables. The results showed that there were direct or indirect effects of exogenous variables of school culture and work motivation on endogenous variables of student learning outcomes with teacher performance as an intervening variable. The magnitude of the significance value of each variable is discussed.

Keywords: learning outcomes, school culture, work motivation, teacher performance, learning

\section{INTRODUCTION}

Education is essentially a process of building a nation's civilization. Therefore, education must always rely on the concepts of growth, development, renewal, and 
sustainability so that the implementation of education must be managed professionally (Usman, 2014). In other words, improving the quality of education is an endeavor that must be pursued continuously so that expectations for quality and relevant education can be achieved (Fadhli, 2017). Quality human resources can only be realized with quality education. Quality education is education that is able to develop positive potentials that are latent in students (Widodo, 2016). It is undeniable that to realize quality education, one of the determining instruments is the presence of qualified teachers as well (Efferi, 2015). The teacher as a party directly involved in the learning process in the classroom, has a very vital role in improving the quality of their students. The success of the education process can be said to depend very much on the role of the teacher in the school (Muhson, 2004). In fact, teachers are the most influential component in creating quality educational processes and outcomes (Manik \& Bustomi, 2011). Professional teachers certainly show good performance.

In addition to the teacher factor, school culture also has an important role to encourage the advancement of education. The culture of school organizations that can improve the quality of education is a culture of hard work, always trying to be the best, a sense of ownership and responsibility, prioritizing the progress of students, and a good relationship between fellow school members, as well as a good relationship between school residents and the surrounding community (Ginting, 2011). Because the success of an educational institution is not only supported by complete facilities and infrastructure, qualified teachers or good student input, but the school culture is very instrumental in increasing school effectiveness (Zubaidah, 2016). There are also factors that are not less important are work motivation and teacher performance. Because performance is not interpreted in the work done but the results obtained from carrying out the work (Amtu, 2016). The teacher is an important and valuable asset for the school because if it is managed properly the teacher's performance will be good. This is due to several factors including motivation, and organizational culture (Tetuko, 2012).

But in line with the increasing demands and competition for education quality, aspects such as school culture, work motivation and teacher performance have in fact not been able to answer the expectations as mentioned above. According to Rismawan (2015), this shows that the teaching performance of teachers in Indonesia is still not in line with their dreams. In other words, some teachers have not optimally implemented their teaching performance as expected. The low performance of teachers in learning and then affect the quality of education has been reviewed through various researches, among others: Ginting (2011; Han \& Yin (2016); Tang, Wong \& Cheng (2015); Richardson \& Watt (2010); Rodríguez, Capelleras \& Garcia (2014); Karweti (2010); Wahyudi, Thomas \& Setiyani (2012); and Tetuko (2012). The low work motivation of teachers so that the impact on the quality of the process and learning outcomes is found in several studies, among others: Ardiana (2017); Karweti (2010); and Dewi Pratiwi (2013). The low school culture on teacher performance as well as the learning process and outcomes are found in research conducted by Setiyati (2014); Handayani \& Rasyid (2015).

Indeed some of the preliminary research presented above basically alludes to the role of the teacher, school culture and work motivation, teacher performance and student 
learning outcomes. But the findings referred to have not used path analysis to look for the magnitude of influence between variables that determine the level of student learning outcomes through intervening variables. This research is different, because it offers teacher performance as an intervening variable that directly or indirectly contributes to improving learning outcomes in schools. This research is expected to build a new framework for teacher performance as a variable that plays an important role in creating good learning outcomes. That is, teacher performance requires attention and continuous improvement. Thus, this study was conducted with the aim of investigating the direct and indirect effects of school culture and work motivation on student learning outcomes through teacher performance.

\section{REVIEW OF LITERATURE}

\section{Student Learning Outcomes}

Teachers are an inseparable part of the overall education system that is directly involved in the teaching and learning process, teachers who play a direct role in teaching and educating (Ardiana, 2017). As a professional, the teacher's job as an educator, instructor and trainer should be able to impact on his students. In this case the teacher should be able to continuously improve his performance which is the capital for educational success (Manik \& Bustomi, 2011). Efforts to improve teacher teaching must encourage student learning (Thoonen et al., 2011). Educational psychologists agree that learning in class involves cognitive and affective processes and is strongly influenced by social processes. This implies that students must be able and willing to regulate their cognition, motivation, and emotions, and to adapt to social contexts to facilitate their learning (Boekaerts, 2010).

Is a very important factor for students in educational activities, if a teacher is present in the class and actively provides continuous education and guidance to students, because its existence is one of the keys to success in the teaching and learning process (Palupi, 2014). Every day the teacher interacts directly with students or students through the learning process (Hotimah, 2017). Meaningful learning obtained by students when learning makes students remember the learning material more so that it can influence the learning outcomes obtained (Handini, Gusrayani \& Panjaitan, 2016). Competent teachers will be better able to create effective learning environments and will be better able to manage their classes so that student learning outcomes are at an optimal level (Aritonang, 2008). Even class attendance, midterm and study time have a significant positive effect on learning outcomes (Tetteh, 2018). The teacher has a positive attitude towards teaching reorganization. The teacher also integrates evaluation as part of learning management (Thongnin, Wongwanich \& Piromsombat, 2014).

The existence of factors that influence learning outcomes can be studied internally or externally. Factors that influence the process and student learning outcomes both internal and external factors and the most important instruments are interest, motivation, and teacher (Aritonang, 2008). The solution that can be given so that the learning outcomes of the class can improve and be able to compete is by applying a learning model that is supported by interesting learning media (Kusuma, Wijayati \& Wibowo, 
2008). One way is to create learning that challenges students' thinking power, fosters curiosity, provides ample opportunities to develop insights and fosters student creativity so that they actively respond to lessons (Wahyuni \& Kristianingrum, 2008). Robert Gagne, as quoted by Djiwandono (2002) divides student learning outcomes into five categories namely; verbal information, intellectual skills, motor skills, attitudes and cognitive strategies.

\section{School Culture}

According to Bush \& Middlewood (2005: 47) culture is related to the informal aspects of an organization rather than its legal elements. They focus on the values, beliefs and norms of individuals in the organization and how individual perceptions are fused into a shared meaning. The same thing stated by Armstrong (2006) that organizational or corporate culture is a pattern of values, norms, beliefs, attitudes, and assumptions that may not be articulated but rather shape the way people behave and things are done. Cultural models that recognize hidden meanings and interactions from various levels of the model, namely beliefs, values, norms and standards, and finally behavior (Maxwell \& Ross Thomas, 1991).

The definition of school culture as stated in the School Guidelines for the Development of Cultural Education and National Characters compiled by the Ministry of National Education (2010) clearly addresses this concept. School culture is an atmosphere of school life where students interact with each other, teachers and teachers, counselors and students, between education staff, between education staff and educators and students, and between community group members and school members. The school organizational culture according to Handayani \& Rasyid (2015) is a characteristic of a school that can be identified through its values, attitudes, habits that are displayed, and actions shown by all school personnel that form a special unity of the school system.

School culture refers to a system of values, beliefs and norms that are collectively accepted, and implemented with full awareness as a natural behavior, formed by the environment that creates a common understanding among all elements and personnel of the school be it the principal, teachers, staff, students and if necessary form the same community opinion as the school (Setiyati, 2014). Or a conducive culture where positive values, attitudes, behaviors and habits are preserved, not only encouraging teachers to be creative, but also to improve their innovation performance (Wibowo \& Saptono, 2017). School culture may have an influence on the school community. An effective school culture leads to success in accordance with values, professionalism and building school autonomy (Susilo, Kartowagiran \& Vehachart, 2018).

However, the organizational culture in a school environment will be different from other schools, this difference is due to the environment that affects the organization differently, both external and internal environment of the organization (Manik \& Bustomi, 2011). Support from the school culture and classroom environment influences the improvement of soft skills among middle school students (Ahmad, Chew, Zulnaidi, \& Sobri, 2019). An important variable that drives teacher innovation performance is school culture. Organizational / school culture plays an important role for the emergence 
of teacher creativity and innovation performance (Wibowo \& Saptono, 2017). Norms that are believed in school culture include honesty, fairness, courtesy, and example. The attitude of the school community is respecting time, being objective, and scientific attitude (Wibowo \& Saptono, 2017).

\section{Work Motivation}

Motivation is a process for activating motives into actions or behaviors to meet needs and achieve certain goals (Palupi, 2014). Motivation means what moves a person to make certain choices, to engage in actions, to try and persevere in actions (Dörnyei \& Ushioda, 2013). A teacher can be said to have high work motivation if he is satisfied with his work, has motivation, a sense of responsibility and enthusiasm (Karweti, 2010). Motivation is often said to be the key to work creativity. Work creativity can be enhanced by high work motivation, knowledge and expertise in carrying out positive tasks and roles that a person has (Dimyati, 2006).

Teachers have sufficient motivation to contribute to the achievement of educational goals (Gokce, 2010). Teacher motivation has been identified as a major determinant for student motivation and teaching effectiveness (Han \& Yin, 2016). In an era of teacher shortages, what will motivate individuals to become teachers when the demands on teachers are greater than before and there are many job alternatives to choose from (Sinclair, 2008). Teacher extrinsic motivation has a positive effect on student learning outcomes (König \& Rothland, 2012). Although controlled motivation can lead teachers to adhere to system standards, it is independent motivation that turns their work into meaningful experiences, encouraging them to practice teaching that supports independence (Eyal \& Roth, 2011). Therefore, teachers must work together to produce skilled human resources who are able to enter the workplace in the future (Ahmad, Chew, Zulnaidi, \& Sobri, 2019). Self-perception of abilities related to learning is one of the main sources of motivation, along with a desire to shape the future of children and adolescents and an interest in teaching (Nesje, Brandmo \& Berger, 2018).

\section{Teacher Performance}

Today the term performance has always been the focus of attention of every organization, company, non-governmental organization, educational institution and even government institutions to measure the level of achievement of a program according to the goals set (Amtu, 2015). As an educational institution, schools also absolutely implement a performance management system to measure the achievement of an activity according to the objectives set. Research conducted by Page (2016) has identified four dialectical tensions that support performance management in schools, namely; responsibility to the teacher and responsibility to students; external accountability and professional autonomy; teacher discipline and teacher support; improve the process and practice of improvisation. Correspondingly, Schacter (2001), emphasizes the importance of implementing a system of accountability based on teacher performance that is sustainable, determining teacher quality that leads to professional development targeted to improve teacher teaching practices and student achievement. Given the importance of 
teacher performance in education, efforts are needed to improve teacher performance (Koswara \& Rasto, 2016).

Why is teacher performance so central to improving student achievement and learning outcomes? Because teacher performance is the teacher's effort in improving student learning achievement through teaching (Wahyudi, Thomas \& Setiyani, 2012). In addition, teacher performance is the ability demonstrated by the teacher with regard to the roles, tasks and responsibilities that he carries on the basis of his professional abilities (Setiyati, 2014). Teacher teaching performance is defined as a teacher's work performance in learning as a realization of his competencies to obtain optimal student learning outcomes (Rismawan, 2015). Related to teacher performance, the manifestation of the intended behavior or indicator is to plan learning, carry out learning activities, evaluate learning, and analyze and follow up on the results of the learning evaluation (Azwar \& Murniati, 2015). If connecting better with students is related to performance, then how teachers learn to change their delivery methods so that they can encourage better outcomes (Gilbert, 2018).

\section{METHOD}

\section{Research Variables}

This study was designed using four variables namely; School Culture, Work Motivation, Teacher Performance and Learning Outcomes. School Culture Variables measure the extent of leadership, example, friendliness, tolerance, hard work, discipline, social care, environmental care, nationalism, and responsibility, as established by the Ministry of Education (2010). Indicators of assessment of Work Motivation variables are measured in aspects of being satisfied with work, having motivation, a sense of responsibility and enthusiasm, as suggested by Karweti (2010) and Nesje, Brandmo \& Berger (2018). Teacher Performance Variables are directed at measuring learning planning, implementing learning activities, evaluating learning, and analyzing and following up on learning evaluation results, as suggested by Azwar \& Murniati (2015); Setiyati (2014); and Gilbert (2018). Indicator variable Student Learning Outcomes are directed to measure the achievement of verbal information, intellectual skills, motor skills, attitudes and cognitive strategies as suggested by Gagne quoted by Djiwandono (2002); Wahyuni \& Kristianingrum (2008); and Kusuma, Wijayati \& Wibowo (2008). These indicators are then used to design the questionnaire according to a Likert scale at a range of five points.

\section{Sampling Technique}

The population of this research was 582 participants of professional teacher education in the position of Christian Religious Education Teachers from 26 provinces in Indonesia which took place in the city of Ambon, Maluku province. The population in this study by type is a limited population and by its nature is a homogeneous population (Brahmasari \& Suprayetno, 2009). The technique of determining the sample uses purposive sampling as suggested by Sarwono (2006) because it is a technique of determining the sample with special consideration so that it is suitable as a sample. This technique prioritizes research objectives more than the nature of the population in the 
process of determining the research sample (Bungin, 2005). By using the Slovin sample determination technique as suggested by Amirin (2011), then with a population of 582 then a sample of 213 respondents was set with an error rate of $5 \%$.

\section{Instrument}

The study used a questionnaire as an instrument for data collection. Each variable has a different number of statements according to the study of the underlying theory. Questionnaires were distributed to 213 teacher respondents. Questionnaires returned and answered according to statement were the same as the sample of respondents specified. Thus it is in accordance with the number of 213 samples that have been determined. Each variable was compiled using a Likert Scale with five answer choices to explore the understanding, experience and attitude of each respondent according to the problems and context experienced in each school.

\section{Multivariate Normality}

Multivariate normality analysis of research data shows point 0.120 means the coefficient value is normal because it is smaller than the maximum threshold of 2.58 (Ghozali, 2017) \& (Yanto, Yulianto, Sebayang, \& Mulyaga, 2017). Likewise, the multivariate coefficient kurtosis which shows point 0.126 means that it does not exceed the maximum value limit of 2.58 (Ghozali, 2017) \& (Yanto, Yulianto, Sebayang, \& Mulyaga, 2017), so it can be concluded that the research data are normally distributed. Data normality test results for each variable are seen in the following table.

Table 1

Assessment of Normality

\begin{tabular}{|c|c|c|c|c|c|c|}
\hline Variable & $\min$ & $\max$ & skew & c.r. & kurtosis & c.r. \\
\hline School Culture & 150,000 & 198,000 &,- 130 &,- 775 &,- 797 & $-2,375$ \\
\hline Work Motivation & 150,000 & 199,000 &,- 202 & $-1,206$ &, 150 & ,448 \\
\hline $\begin{array}{l}\text { Teacher } \\
\text { Performance }\end{array}$ & 152,000 & 195,000 &,- 160 &,- 953 &,- 911 & $-2,714$ \\
\hline Learning Outcomes & 151,000 & 198,000 &,- 024 &,- 141 &,- 245 &,- 730 \\
\hline Multivariate & & & & &, 120 & ,126 \\
\hline
\end{tabular}

\section{Data Analysis}

This research uses descriptive, correlation, and path analysis. The purpose of correlation analysis is to provide a comparison with the results of path analysis, because correlation analysis is not influenced by the correlation of other variables (Yanto et al., 2017). Path analysis wants to test the regression equation that involves several exogenous and endogenous variables at once to enable testing of mediating / intervening variables or intermediate variables (Ghozali, 2017). Based on literature review, this research model has two exogenous variables (School Culture and Work Motivation) and two endogenous variables (Teacher Performance and Learning Outcomes). This research model is designed with six hypotheses to be tested simultaneously using path analysis. The model was also tested using the goodness of fit test (Lleras, 2005; Albright \& Park, 2009; Ghozali, 2017; Yanto et al., 2017). To test goodness of fit, this study uses six 
indices namely Chi Squared, Goodness of Fit Index (GFI), Goodness of Fit Index (AGFI), Root Mean Square of Approximation (RMSEA), Normed Fit Index (NFI), and Comparative Fit Index (CFI), and CMIN / d.f. as suggested by Ghozali (2017), and Yanto et al., (2017). The threshold for this index is as follows: Chi-square must have a p-value not significant or ( $p>0.05$ ); fit values for GFI, AGFI, NFI, CFI must be above 0.90; RMSEA value must be below 0.08; and the value of CMIN / d.f. must be under 3.0 (Lleras, 2005; Albright \& Park, 2009; Ghozali, 2017; Yanto et al., 2017).

\section{Theoretical Models and Hypothesis}

The theoretical model used in this study is shown in the following figure.

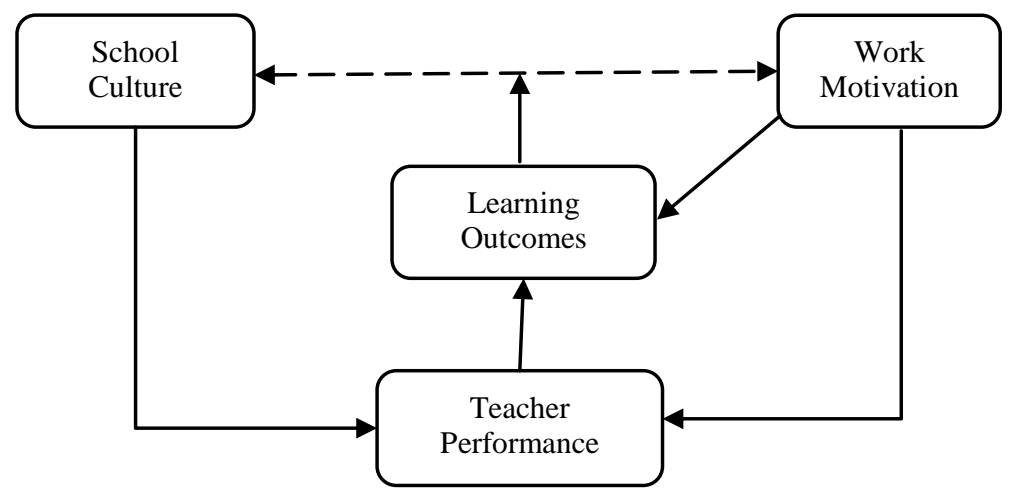

Figure 1

Theoretical Models of Direct and Indirect Influence of Exogenous and Indogenous Variables with Teacher Performance as an Intervening Variable

Based on the context of the problem and literature review, this study was designed using six hypotheses, namely: (H1): School Culture influences Teacher Performance; H2: Work Motivation influences Learning Outcomes; (H3): Work Motivation influences Teacher Performance; (H4) Teacher Performance influences Learning Outcomes; (H5) School culture influences learning outcomes through teacher performance; and (H6): Work Motivation influences Learning Outcomes through Teacher Performance.

\section{FINDINGS}

\section{Descriptive Analysis}

Descriptive analysis shows that the minimum score of the School Culture variable scores 150 and the maximum is 198 with a mean of 174.28. This means that School Culture has played a significant role in improving Teacher Performance so that it can improve Student Learning Outcomes. Work motivation with a minimum score of 150 and a maximum of 199 with a mean of 177.99. Interpreted that Work Motivation has contributed positively to Teacher Performance as well as Student Learning Outcomes. Teacher performance with a minimum score increased a little 152 and a maximum of 195 with a mean of 175.00 . In other words, Teacher Performance has supported the 
achievement of Student Learning Outcomes. Finally, Student Learning Outcomes with a minimum score of 151 and a maximum of 198 with a mean of 175.55 . This means that student learning outcomes can improve well through the support of school culture, work motivation and teacher performance. More outlined in the form of descriptive analysis table research results.

Table 2

Descriptive Statistics

\begin{tabular}{llllll}
\hline Descriptive Statistics & N & Min. & Max. & Mean & Std. Deviation \\
\hline School Culture & 213 & 150 & 198 & 174,28 & 11,303 \\
Work Motivation & 213 & 150 & 199 & 177,99 & 10,169 \\
Teacher Performance & 213 & 152 & 195 & 175,00 & 10,899 \\
Learning Outcomes & 213 & 151 & 198 & 175,55 & 10,210 \\
Valid N (listwise) & 213 & & & & \\
\hline
\end{tabular}

\section{Correlation}

The results of correlation analysis show that there is a relationship between learning outcomes variables and teacher performance $(0.655, \mathrm{p}<0.01)$, work motivation $(0.645$, $\mathrm{p}<0.01)$. School culture does not correlate directly but through teacher performance variables with coefficients $(0.493, \mathrm{p}<0.01)$. As an intervening variable, teacher performance correlates with school culture $(0.706, \mathrm{p}>0.01)$, and with work motivation $(0.723, p>0.01)$, school culture and work motivation with coefficients $(0.597, p>0.01)$. In other words, an increase in student learning outcomes is positively correlated with a dynamic and creative school culture, high work motivation and improved teacher performance in learning. The following table presents a matrix of correlation values between the variables studied.

Table 3

Correlations Matrix

\begin{tabular}{lllll}
\hline & $\begin{array}{l}\text { School_ } \\
\text { Culture }\end{array}$ & $\begin{array}{l}\text { Work_ } \\
\text { Motivation }\end{array}$ & $\begin{array}{l}\text { Teacher_ } \\
\text { Performance }\end{array}$ & $\begin{array}{l}\text { Learning_ } \\
\text { Outcomes }\end{array}$ \\
\hline School_Culture & 1,000 & & & \\
Work_Motivation &, 597 & 1,000 & & \\
Teacher_Performance &, 706 &, 723 & 1,000 & \\
Learning_Outcomes &, 493 &, 645 &, 655 & 1,000 \\
\hline
\end{tabular}

\section{Path Analysis}

This study uses a path diagram with the help of the AMOS 21 program to test how much the direct and indirect effects of the six proposed hypotheses are; H1, H2, H3, H4, H5, and H6, as stated earlier. After being tested, all hypotheses were accepted because they met the established criteria. The following figure presents the antecedents of improving student learning outcomes using teacher performance as an intervening variable. 


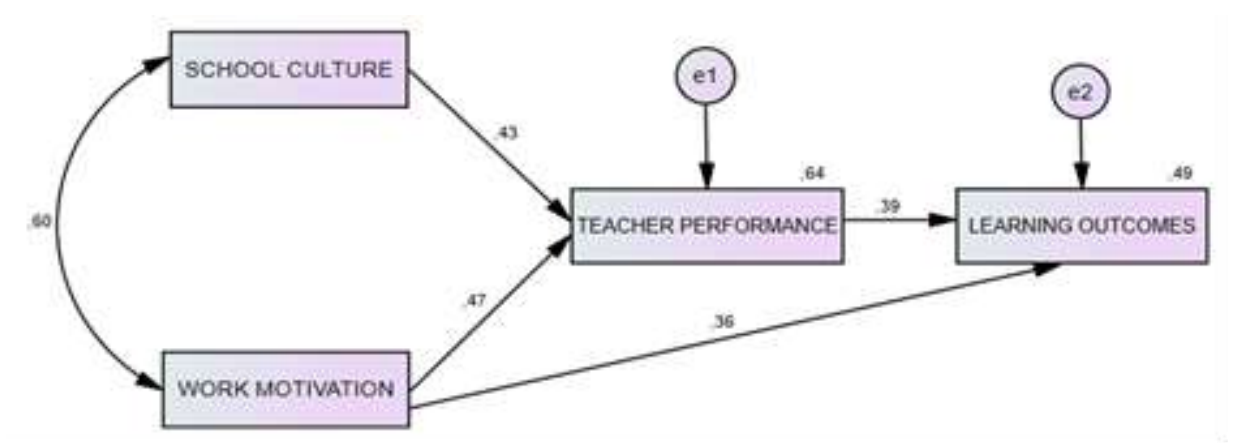

Figure 2

Path Analysis Chart

The results of the path analysis to test the hypothesis about the direct influence between exogenous and endogenous variables with teacher performance as an intervening variable indicate that the direct influence of school culture on teacher performance is 0.426 or $42.6 .7 \%$. These results prove that the hypothesis (H1) is accepted. The direct effect of work motivation on learning outcomes obtained value of 0.360 or $36.0 \%$. These results prove that the hypothesis $(\mathrm{H} 2)$ is accepted. The direct influence of work motivation on teacher performance is 0.468 or $46.8 \%$. These results prove that the hypothesis (H3) is accepted. Furthermore, the direct effect of teacher performance on learning outcomes obtained a value of 0.394 or $39.4 \%$. These results prove that the hypothesis (H4) is accepted. The following table explains the test results of the effects of each variable.

Table 4

Standardized Direct Effects

\begin{tabular}{llll}
\hline & $\begin{array}{l}\text { School_ } \\
\text { Culture }\end{array}$ & $\begin{array}{l}\text { Work_ } \\
\text { Motivation }\end{array}$ & $\begin{array}{l}\text { Teacher_ } \\
\text { Performance }\end{array}$ \\
\hline Teacher_Performance &, 426 &, 468 &, 000 \\
Learning_Outcomes &, 000 &, 360 &, 394 \\
\hline
\end{tabular}

Hypothesis test results regarding the indirect effect between exogenous and endogenous variables with teacher performance as an intervening variable indicate that the indirect effect of school culture on teacher performance subsequently to learning outcomes = $(0.426)(0.394)=0.168$. So, total effect: direct + indirect $=0.426+0.168=0.168$. That is, the influence of school culture on learning outcomes through teacher performance is only $16.8 \%$. These results prove that the hypothesis (H5) is accepted. The indirect effect of work motivation on subsequent teacher performance to learning outcomes $=(0.468)$ $(0.394)=0.185$. So, total effect: direct + indirect $=0.360+0.185=0.545$. That is, the effect of work motivation on learning outcomes through teacher performance by $54.5 \%$. These results prove that the hypothesis (H6) is accepted. The following table explains the test results of the indirect effects of each variable. 
Table 5

Standardized Indirect Effects

\begin{tabular}{llll}
\hline & School_ & Work_ & Teacher_ \\
& Culture & Motivation & Performance \\
\hline Teacher_Performance &, 000 &, 000 &, 000 \\
Learning_Outcomes &, 168 &, 185 &, 000 \\
\hline
\end{tabular}

\section{Goodness of Fit Test}

After the goodness of fit test, the developed path diagram model gives Chi Square of 6.906 ( $p>0.05$ ), it is concluded that the developed model has been supported by empirical data. An RMSEA value of 0.167 is considered suitable, because it is close to a predetermined threshold, which is below the 0.08 threshold. Meanwhile, values in the CMIN / df, GFI, AGFI, NFI, and CFI categories showed results that were very much in accordance with the specified threshold. Thus, it was concluded that the model met most of the requirements in the Goodness of Fit Test.

Table 6

Goodness of Fit Test

\begin{tabular}{llll}
\hline Index & Cut-off Value & Empirical Test & Remark \\
\hline Chi Squared & $\alpha \geq 5 \%$ & $6.906,(p=0.009)$ & Fit \\
CMIN/d.f. & $\leq 3.0$ & 1.00 & Fit \\
GFI & $\geq 0.9$ & 0.984 & Fit \\
AGFI & $\geq 0.9$ & 0.842 & Fit \\
NFI & $\leq 0.9$ & 0.985 & Fit \\
CFI & $\geq 0.9$ & 0.987 & Fit \\
RMSEA & $\leq 0.08$ & 0.167 & Fit \\
\hline
\end{tabular}

\section{DISCUSSION}

The low quality of education is determined by various factors. Low teacher performance certainly impacts directly on the low quality of education. This shows that the teaching performance of teachers in Indonesia is still not in accordance with the goals (Rismawan, 2015). This research offers one strategy to encourage student learning outcomes in schools through improving teacher performance. Teacher performance becomes an important factor because it bridges other factors that directly or indirectly contribute to student learning outcomes. With increasing teacher performance, student learning outcomes will increase. Likewise, improving teacher performance and student learning outcomes will encourage national quality education.

The results of the correlation analysis show that there is a significant relationship between school culture and teacher performance. Path analysis also shows the same results because there is a significant influence between school culture and teacher performance, a value of $42.6 \%$ is obtained. This proves that teacher performance is influenced by school culture. In other words, the existence of hopes and demands for improving teacher performance is also largely determined by the support of school culture. A healthy, dynamic and creative school culture naturally will encourage teacher performance in the process and learning outcomes. In accordance with the Ministry of 
National Education guidelines (2010), school culture consists of values that directly or indirectly determine the progress of the school, namely; leadership, example, friendliness, tolerance, hard work, discipline, social care, environmental care, nationalism, and responsibility. This finding is in line with previous research that increasing teacher performance is not solely due to the intrinsic encouragement of every teacher, but also requires the atmosphere, climate and culture of schools that are created dynamically, creatively and innovatively (MacNeil, Prater \& Busch, 2009; Setiyati, 2014; Handayani \& Rasyid, 2015; Tetuko, 2012; Ginting, 2011; Purwoko, 2018; and Sugeng, 2012).

Analysis of the magnitude of the effect of work motivation on learning outcomes shows a significance value of $36.0 \%$. This means that teacher work motivation is one of the driving aspects for students in producing learning achievement in school. Teachers who have high work motivation, will motivate students to study hard. Every student has an ideal to succeed in every learning, but they also need the role of the teacher who motivates them to succeed in learning. As suggested by Han \& Yin, (2016), that teacher work motivation becomes the main determinant for student motivation and effectiveness in teaching. Work motivation will move a person to make certain choices and take action (Dörnyei \& Ushioda, 2013). These findings also confirm the results of previous studies which prove that high teacher work motivation can contribute positively to learning outcomes and even academic achievement of students at school. Conversely, low teacher motivation will directly affect student learning outcomes. High and low teacher's work motivation is in contact with student learning outcomes (Budiman \& Irianto, 2015; Jamali \& Prasojo, 2013; Zubaidah, 2016; Hendrawati \& Prasojo, 2015).

Analysis of the direct effect of work motivation on teacher performance shows a significant value of $46.8 \%$. A strong motivation in every teacher to work will give satisfying results. Teachers who have low work motivation, certainly have low performance as well. As Eyal \& Roth (2011) suggested that inner motivation will transform teacher's work into meaningful experiences, encouraging teachers to practice learning that supports independence. This finding is in line with previous studies which found that teacher work motivation has a direct impact on the performance produced by a teacher. Teachers who work hard can improve their performance in learning (Setiyati, 2014; Eros, 2014; Handayani \& Rasyid, 2015; Tetuko, 2012; Rismawan, 2015; Rahardja, 2004).

One factor that determines student learning outcomes is the teacher. Analysis of the direct effect of teacher performance on student learning outcomes gives a significance value of $39.4 \%$. The contribution of teacher performance to student learning outcomes is indeed not new because teacher performance is measured through learning success (Wahyudi, Thomas \& Setiyani, 2012), developing tasks and roles in a professional manner (Setiyati, 2014), the ability to change learning methods (Gilbert, 2018), can plan, implement, evaluate, and analyze and follow up on the results of evaluation of learning (Azwar \& Murniati, 2015). Even though today's learning resources can be obtained digitally based online, the teacher's role is still considered central in increasing interest, motivation, learning outcomes and student achievement in school. This finding 
is in line with previous studies that teacher performance contributes positively to student learning outcomes (Zubaidah, 2016); (Palupi, 2014); (Azwar \& Murniati, 2015); (Nuchiyah, 2007); (Esminarto, Sukowati, Suryowati \& Anam, 2016); and (Palupi, 2014).

The results of the analysis of the indirect effect of school culture on learning outcomes through teacher performance obtained a significance value of $16.8 \%$. The magnitude of the influence of school culture on learning outcomes through teacher performance is indeed not comparable with the results of testing other variables. This emphasizes that the culture of each school needs to encourage teacher performance in an integrated and continuous manner so that it can encourage student learning outcomes. Both teachers and students need a school culture that is creative, productive, dynamic and innovative in order to stimulate the teacher's interest in developing performance, and motivate students to find an atmosphere of learning that facilitates their success in learning. Five categories of learning outcomes as suggested by Djiwandono (2002), namely; verbal information, intellectual skills, motor skills, attitudes and cognitive strategies. This finding is in line with research by Ohlson (2009) and Brady (2005), which emphasizes the importance of school culture encouraging improvement in student learning outcomes.

Finally, an analysis of the indirect effect of work motivation on learning outcomes through teacher performance obtained a significance value of $54.5 \%$. This result confirms that student learning outcomes are closely related to teacher performance and teacher work motivation. Teacher performance will increase if work motivation increases, it will directly contribute positively to student learning outcomes. These findings also emphasize the importance of building work motivation. Because high motivation to work has a positive impact on increasing performance. Furthermore, increasing teacher performance will be realized through the process and student learning outcomes (Setiyati, 2014; Eros, 2014; Handayani \& Rasyid, 2015; Tetuko, 2012; Rismawan, 2015; Rahardja, 2004).

\section{CONCLUSION}

After describing the research findings, it is concluded that there is a direct or indirect influence of school culture and work motivation on student learning outcomes through teacher performance. Through teacher performance, school culture and work motivation can be encouraged and improved professionally so as to improve student learning outcomes well.

\section{SUGGESTIONS AND RECOMMENDATIONS}

It is recommended that teacher performance be improved through various training and guidance by the Office of Education, Supervisors and School Principals. School culture and work motivation need to be encouraged and improved in order to be able to move every school community including teachers to improve learning outcomes through work performance every day. This finding certainly requires future development. Other variables such as education level, teacher welfare, parental and community support can 
be used to examine the relationship and influence directly or indirectly on student learning outcomes at school.

\section{REFERENCES}

Ahmad, A. R., Chew, F. P., Zulnaidi, H., \& Sobri, K. M. (2019). Influence of school culture and classroom environment in improving soft skills amongst secondary schoolers. Int J of Ins, 12(2), 259-274. https://doi.org/10.29333/iji.2019.12217a.

Albright, J. J., \& Park, H. M. (2009). Confirmatory factor analysis using Amos, LISREL, Mplus, SAS/STAT CALIS.

Amirin, T. M. (2011). Study Population and Sample 4: Sample Size of the Slovin Formula. Jakarta: Erlangga.

Amtu, O. (2015). School principal performance evaluation. Bandung: Alfabeta.

Amtu, O. (2016). Human resource management in the field of education. Bandung: Alfabeta.

Ardiana, T. E. (2017). The effect of teacher's work motivation on vocational accounting teacher performance in Madiun City. Journal of Accounting and Tax, 17(02).

Aritonang, K. T. (2008). Interest and motivation in improving student learning outcomes. Journal of Sower Education, 7(10), 11-21.

Armstrong, M. (2006). A handbook of human resource management practice. London: Kogan Page Limited.

Azwar, K., \& Murniati, A. R. (2015). The effect of certification and teacher performance on improving student learning outcomes in SMP Negeri 2 Banda Aceh. Journal of Educational Administration: Unsyiah Postgraduate Program, 3(2).

Boekaerts, M. (2010). Motivation and self-regulation: Two close friends. In T. C. Urdan, \& S. A. Karabenick (Eds.), The decade ahead: Applications and contexts of motivation and achievement (pp. 69-108). Emerald Group Publishing Limited.

Brady, P. (2005). Inclusionary and exclusionary secondary schools: The effect of school culture on student outcomes. Interchange, 36(3), 295-311.

Brahmasari, I. A., \& Suprayetno, A. (2009). The effect of work motivation, leadership and organizational culture on employee job satisfaction and its impact on company performance (case study at PT. Pei Hai International Wiratama Indonesia). Journal of Management and Entrepreneurship, 10(2), 124-135.

Budiman, F., \& Irianto, A. (2015). Effects of teacher teaching motivation and teacher teaching skills on student learning outcomes of state high schools in the city of Bukittinggi. Journal of Economic Education Review, 2(2).

Bungin, B. (2005). Quantitative research methodology: Communication. Economics and public policy and other social sciences. Jakarta: Prenada Media.

Dewi Pratiwi, S. (2013). The effect of work motivation, job satisfaction, principal leadership according to teacher perceptions and school climate on the performance of 
economics teachers of public middle schools in Wonogiri Regency. (Unpublished doctoral dissertation).

Dimyati, M. (2006). Teaching and learning. Jakarta, Rineka Cipta.

Djiwandono, S. E. (2002). Educational psychology. Jakarta: Grasindo

Dörnyei, Z., \& Ushioda, E. (2013). Teaching and researching: Motivation. Routledge.

Efferi, A. (2015). Teacher education models in improving education quality. Quality, $3(2), 237-256$.

Eros, E. (2014). The effect of teacher motivation and discipline on teacher performance in state junior high school in Brebes District, Brebes Regency, Central Java. Journal of Public Administration and Bureaucracy, 1(1).

Esminarto, E., Sukowati, S., Suryowati, N., \& Anam, K. (2016). Implementation of the STAD model in improving student learning outcomes. Journal of Research and Conceptual, 1(1), 16-23.

Eyal, O., \& Roth, G. (2011). Principals' leadership and teachers' motivation: Selfdetermination theory analysis. Journal of Educational Administration, 49(3), 256-275. https://doi.org/10.1108/09578231111129055.

Fadhli, M. (2017). Management of improving the quality of education. Journal of Educational Management Studies, 1(2), 215-240.

Gokce, F. (2010). Assessment of teacher motivation. School Leadership and Management, 30(5), 487-499. https://doi.org/10.1080/13632434.2010.525228.

Gilbert, M. (2018). Student performance is linked to connecting effectively with teachers. Journal of Research in Innovative Teaching \& Learning, 12(3), 311-324. https://doi.org/10.1108/JRIT-05-2018-0010.

Ghozali, I. (2017). Structural equation model: Concepts and applications with the AMOS 24 program. Bayesian SEM update. Semarang: Badan Penerbit Universitas Diponegoro.

Ginting, B. (2011). Relationship between school organizational culture and headmaster's leadership and the performance of high school teachers in Binjai City. Jurnal Tabularasa, 8(01), 61-72.

Han, J., \& Yin, H. (2016). Teacher motivation: Definition, research development and implications for teachers. Cogent Education, 3(1), 1217819. https://doi.org/10.1080/2331186X.2016.1217819.

Handini, D., Gusrayani, D., \& Panjaitan, R. L. (2016). Application of the contextual teaching and learning model improves student learning outcomes of class IV on style material. Journal of Scientific Pens, 1(1), 451-460.

Handayani, T., \& Rasyid, A. A. (2015). The influence of school principal leadership, teacher motivation, and organizational culture on the teacher performance of Wonosobo high school. Journal of Educational Management Accountability, 3(2), 264-277. 
Hendrawati, A., \& Prasojo, L. D. (2015). The influence of school principal transformational leadership, teacher work motivation, and school culture on learning achievement. Journal of Educational Management Accountability, 3(2), 141-157.

Hotimah, H. (2017). Unesa's teacher professional education strategy (PPG) in developing pedagogic and professional competencies of PPG participants PASCA SM3T. Moral and Citizenship Study, 5(01).

Jamali, A., \& Prasojo, L. D. (2013). The influence of the principal's managerial competence, environment, teacher's motivation, on the achievement of Muhammadiyah high school students in Yogyakarta. Journal of Educational Management Accountability, 1(1), 8-21.

Karweti, E. (2010). The influence of the principal's managerial ability and factors that influence work motivation on the performance of SLB teachers in Subang Regency. Educational Research Journal, 11(2), 77-89.

The Ministry of National Education. (2010). School Guidelines for the Development of National Culture and Character Education. Jakarta.

König, J., \& Rothland, M. (2012). Motivations for choosing teaching as a career: Effects on general pedagogical knowledge during initial teacher education. Asia-Pacific $J$ of Teacher Edu, 40(3), 289-315. https://doi.org/10.1080/1359866X.2012.700045.

Koswara, K., \& Rasto, R. (2016). Teacher competency and performance based on professional certification. Journal of Office Management Education, 1(1), 61-71.

Kusuma, E., Wijayati, N., \& Wibowo, L. S. (2008). SAVI-based NHT type cooperative learning to improve chemistry learning outcomes of the subject of reaction rates. Journal of Chemical Education Innovation, 2(1).

Lleras, C. (2005). Path analysis. Encyclopedia of social measurement, 3(1), 25-30.

MacNeil, A. J., Prater, D. L., \& Busch, S. (2009). The effects of school culture and climate on student achievement. Int Journal of Leadership in Education, 12(1), 73-84.

Manik, E., \& Bustomi, K. (2011). Effect of principal leadership, organizational culture and work motivation on teacher performance in Rancaekek 3 middle school. Journal of Economics, Business \& Entrepreneurship, 5(2), 97-107.

Maxwell, T. W., \& Ross Thomas, A. (1991). School climate and school culture. Journal of Educational Administration, 29(2). https://doi.org/10.1108/09578239110003309.

Muhson, A. (2004). Enhancing teacher professionalism: A hope. Journal of Economics and Education, 1(2).

Nesje, K., Brandmo, C., \& Berger, J. L. (2018). Motivation to become a teacher: A Norwegian validation of the factors influencing teaching choice scale. Scandinavian $J$ of Edu Research, 62(6), 813-831. https://doi.org/10.1080/00313831.2017.1306804.

Nuchiyah, N. (2007). Effects of principal leadership and teacher teaching performance on student learning achievement. Journal of Basic Education, 5(7), 1-4. 
Ohlson, M. (2009). Examining instructional leadership: A study of school culture and teacher quality characteristics influencing student outcomes. Florida Journal of Educational Administration \& Policy, 2(2), 102-124.

Page, D. (2016). Understanding performance management in schools: A dialectical approach. International Journal of Educational Management, 30(2), 166-176. https://doi.org/10.1108/IJEM-06-2014-0087.

Palupi, R. (2014). The relationship between student motivation and student perceptions of teacher performance in managing learning activities with science learning outcomes of grade viii students at middle school 1 Pacitan. Journal of Educational and Learning Technology, 2(2).

Purwoko, S. (2018). The influence of school principal leadership, teacher commitment, teacher work discipline, and school culture on vocational teacher performance. Journal of Educational Management Accountability, 6(2), 150-162.

Rahardja, A. T. (2004). The relationship between interpersonal communication of teachers and teacher's work motivation with teacher performance of BPK PENABUR Jakarta SMUK. Journal of Sower Education, 3(3).

Richardson, P. W., \& Watt, H. M. (2010). Current and future directions in teacher motivation research. In T. C. Urdan, \& S. A. Karabenick (Eds.), The decade ahead: Applications and contexts of motivation and achievement (pp. 139-173). Emerald.

Rismawan, E. (2015). The effect of principal supervision and teacher achievement motivation on teacher teaching performance. J of Educational Administration, 22(1).

Rodríguez, A. M., Capelleras, J. L., \& Gimenez Garcia, V. M. (2014). Teaching performance: Determinants of the student assessment. Academia Revista Latinoamericana de Administración, 27(3), 402-418. https://doi.org/10.1108/ARLA-112013-0177.

Sarwono, J. (2006). Quantitative and qualitative research methods. Yogyakarta: Graha Ilmu.

Setiyati, S. (2014). Effects of principal leadership, work motivation, and school culture on teacher performance. J of Technology and Vocational Education, 22(2), 200-206.

Schacter, J. (2001). Teacher performance-based accountability: Why, what and how. Retrieved March, 27, 2003.

Sinclair, C. (2008). Initial and changing student teacher motivation and commitment to teaching. Asia-Pacific Journal of Teacher Education, 36(2), 79-104. https://doi.org/10.1080/13598660801971658.

Sugeng, S. (2012). The influence of principal's managerial competence and school culture on the performance of public middle school teachers in Kudus Regency. Educational Management, l(1). 
Susilo, M. J., Kartowagiran, B., \& Vehachart, R. (2018). Modeling of cultural effect on school autonomy at religion-based school in Indonesia. Jurnal Pendidikan IPA Indonesia, 7(3), 364-375. https://doi.org/10.15294/jpii.v7i3.12445.

Tang, S. Y., Wong, A. K., \& Cheng, M. M. (2015). The preparation of highly motivated and professionally competent teachers in initial teacher education. Journal of Education for Teaching, 4l(2), 128-144. https://doi.org/10.1080/02607476.2015.1010875.

Tetuko, B. (2012). The effect of work motivation, organizational culture, principal leadership on job satisfaction and performance of private high school teachers in Grobogan Regency. Educational Management, 1(2).

Tetteh, G. A. (2018). Effects of classroom attendance and learning strategies on the learning outcome. Journal of International Education in Business, 11(2), 195-219. https://doi.org/10.1108/JIEB-01-2017-0004.

Thongnin, P., Wongwanich, S., \& Piromsombat, C. (2014). Multi-task integration as a strategy for improving teacher performance and student learning. Procedia-Social and Behavioral Sciences, 116, 1919-1924. https://doi.org/10.1016/j.sbspro.2014.01.495.

Thoonen, E. E., Sleegers, P. J., Oort, F. J., Peetsma, T. T., \& Geijsel, F. P. (2011). How to improve teaching practices: The role of teacher motivation, organizational factors, and leadership practices. Educational administration quarterly, 47(3), 496-536. https://doi.org/10.1177/0013161X11400185.

Usman, A. S. (2014). Improving the quality of education through the implementation of school based management. Journal of Scientific Didactic: Scientific Media of Education and Teaching, 15(1), 13-31.

Wahyudi, A., Thomas, P., \& Setiyani, R. (2012). The effect of work discipline, work motivation, and school principal supervision on teacher performance. Economic Education Analysis Journal, 1(2), 1-8.

Wahyuni, S., \& Kristianingrum, A. (2008). Improve chemistry learning outcomes and active role of students through PBI models with interactive CD media. Journal of Chemical Education Innovation, 2(1).

Wibowo, A., \& Saptono, A. (2017). Intrapreneurship leadership, school culture and teacher innovation performance. $J$ of Economic and Business Edu, 5(2), 176-193.

Widodo, H. (2016). A portrait of education in Indonesia and its readiness to face the Asian economic community (AEC). Journal of Education and Society, 13(2), 293-308.

Yanto, H., Yulianto, A., Sebayang, L. K. B., \& Mulyaga, F. (2017). Improving the compliance with accounting standards without public accountability (SAK ETAP) by developing organizational culture: A case of Indonesian SMEs. Journal of Applied Business Research, 33(5), 929.

Zubaidah, S. (2016). The influence of school culture and teacher work motivation on the quality of education in Vocational high School 1 Pabelan. Proceedings of Educational Sciences, 1(2). 